\title{
Improvement Of Sobel \& Canny Edge Evoked Technique Using Mathematics Morphology Operation
}

\author{
Rachmat $^{1}$, Nurhaedar ${ }^{2}$ \\ ${ }^{12}$ Program Studi Teknik Informatika, Politeknik Informatika Nasional \\ Jln. Sultan Alauddin No. 250 Makassar \\ 1'rachmat@polinas.ac.id, ${ }^{2}$ nurnurhaedar@gmail.com
}

\begin{abstract}
Abstrak
Saat ini beberapa metode yang peneliti gunakan untuk mempermudah pemrosesan citra yaitu metode filtrasi, penghilangan noise, dan deteksi tepi. Masing-masing memiliki banyak cara khusus untuk menyempurnakan gambar atau membantu pemrosesan langkah selanjutnya. Untuk bidang tertentu seperti kesehatan dan kedokteran atau citra bangunan 2D, beberapa penelitian menggunakan pendekatan morfologi dan non morfologi. Pendekatan morfologi yang digunakan seperti algoritma Dilation, Opening atau Erotion telah menarik perhatian siswa sejak beberapa dekade terakhir. Dalam makalah ini, kami membahas implementasi Pembukaan dan Dilatasi untuk jenis citra tertentu. Menghasilkan judul ini, kami mendapatkan beberapa tingkat perbaikan untuk beberapa tujuan seperti deteksi tepi. Dan pada hasil percobaan didapatkan bahwa operasi morfologi sesuai untuk meningkatkan metode deteksi tepi yang sobel dan cerdik. deteksi tepi banyak digunakan pada bidang penelitian saat ini untuk membantu penelti dalam meneliti ojek 2D berdimensi untuk menghilangkan noise yang timbulkan pada suatu citra digital yang dapat mempengaruhi kualitas citra dengan menggunakan metode morfologi ini dimana citra akan didilasi baik secara opening maupun erosi
\end{abstract}

Kata kunci: dilatasi, operasi morfologi bukaan, strel.

\begin{abstract}
Nowadays some of the methods which researchers used to ease image processing i.e filtration method, noise removal, and edge detection. Each of these has many particular ways in order to enhance images or help for next step processing. For particular fields like health and medical or $2 D$ building images, some researches utilize morphological and non-morphological approach. Morphological approaches which use like Dilation, Opening or Erotion algorithm had placed students attention since last decades. In this paper, we discuss Opening and Dilation implementation for certain images type. Resulting in this title, we get some improvement level for some purpose like edge detection. And in experiment results, we got that Morphological operation is appropriate to improve sobel and canny method of edge detection. Edge detection is widely used in the current field of research to assist researchers in researching $2 D$ motorcycle taxis with dimensions to remove noise that can occur in a digital image that can affect image quality by using this morphological method where the image will be distilled both openly and erosion
\end{abstract}

Keywords: dilation, opening morphology operation, strel.

\section{INTRODUCTION}

According to Fahmi [1], image processing using a computer requires digital images as input. Digital images are two dimensional images that can be displayed on a computer monitor as a finite set of (discrete) digital values called pixels (picture elements). In image processing, we use morphology and non-morphology method for improvement or restoration. 
From [2][3], morphology approach uses mathematical concept for structuring elementselements in an image. The morphological algorithm like dilation, erosion, opening and closing have become a solution to make image processing easier[2][4]. In [4], they restoring the image using morphology operation based dilation, closing, and opening operations. Arini and friends using dilation, filling holes and opening operation for 25 car images to obtain 'Plat Nomor Polisi kendaraan' position. After the experiment, they get $80 \%$ success rate in result [5]. Syed and partner [3] using combinations of erosion and dilation as morphological operation after canny edge detection. Besides that, Retno and partners [6] screening the shape and size of leukocyte cell nucleus based on morphological image. The system can measure the diameter length of the cell.

Morphology is good for smoothing edge, eliminating narrow sections, and eliminating thin bulges. The dilation operation is done to increase the size of the object segment by adding layers around the object $[2,6]$. In this work, we use dilation and opening operation. We use five sample images by random to implement the concept of morphology technique. We do the experiment by marked the positive and negative results. Because the trusty and well recommended of sobel method [7], along with canny we only used this two edge detection methods.

\section{MORPHOLOGY METHODS}

\section{Dilation}

Two fundamental morphological operations - erosion and dilation are based on Minkowski operations. This dilation needs a strel (structure element) as a parameter. The dilation of a set $\mathrm{X}$ by a structuring element $\mathrm{B}$ is denoted by $\mathrm{Sb}(\mathrm{X})$ and is defined as the locus of points $\mathrm{X}$ such that $\mathrm{B}$ hits $\mathrm{X}$ when its origin coincides with $\mathrm{x}[2]$ :

$$
\delta_{B}(X)=\left\{\mathbf{x} \mid B_{\mathbf{x}} \cap X \neq \emptyset\right\}
$$

\section{Closing}

The closing operation is a combination of erosion and dilation operations that sequentially performed. Closing operation function to eliminate or close the small holes which exist in the object segment [8]. The closing operation is useful for smoothing contours and eliminating small holes. The definition is as follows:

$$
A \bullet B=(A \oplus B) \Theta B
$$

\section{Opening}

The opening operation is an erosion operation followed by a dilation using the same structural elements. This operation is useful for refining the object's constructs and removing the entire pixel in an area that is too small to occupy by the structuring element. In other words, all the late paper structures that are smaller in size than the structural elements will be eliminated by erosion and then the smoothing is done through dilation. Definition of opening operation as follows:

$$
A \mathrm{o} B=(A \Theta B) \oplus B
$$

The opening operation is often said to be idempotent [9]. That is, if an image has been subjected to opening operation, an imposition of opening with element of the same instructor does not bring any effect. This property can be written mathematically as follows:

$(A \circ B) \mathrm{o} B=(A \circ B)$ 
The opening operator can be utilized as a low pass filter, a high pass filter, or as a fieldescaped filter if the constructor element is in the form of a disc [10]. Here is the formula:

a. filter (low-pass): $A \circ B^{h}$;

b. filter (high-pass): $A-\left(A \circ B^{h}\right)$;

c. filter (band-pass): $\left(A \circ B^{h l}\right)-\left(A \circ B^{h 2}\right)$, with diameter $\mathrm{B}^{\mathrm{h} 1}<\mathrm{B}^{\mathrm{h} 2}$

An example of the difference between the opening and closing operations on the grayed images can be seen in Fig. 1. It appears that opening operations tend to eliminate a bright but small part (note the eye on the opening). The closing operation maintains a small, light-colored object.

\section{Sobel \& Canny Edge Detection} [3]:

Edge detection process using canny algorithm could be expounded into five subprocesses

1. Smoothing: We perform smoothing or blurring operation to remove noise from the image.

2. Finding gradients: Edges should be marked only in those areas where large magnitudes are obtained. After getting the gradients of the image.

3. Non-maximum suppression: Only local maxima should be considered as edges.

4. Double thresholding: Double thresholding task determines prospective edge.

5. Edge tracking by hysteresis: Final edges can be obtained after suppressing all the edges that are not connected to a strong or very certain edges.

Sobel's operator edge detection was introduced by Irwin Sobel in 1970. This operator is a $3 \times 3$ matrix.

\section{Sobel \& Canny Improvement}

We use main operation of morphological like dilation and opening to do this project.

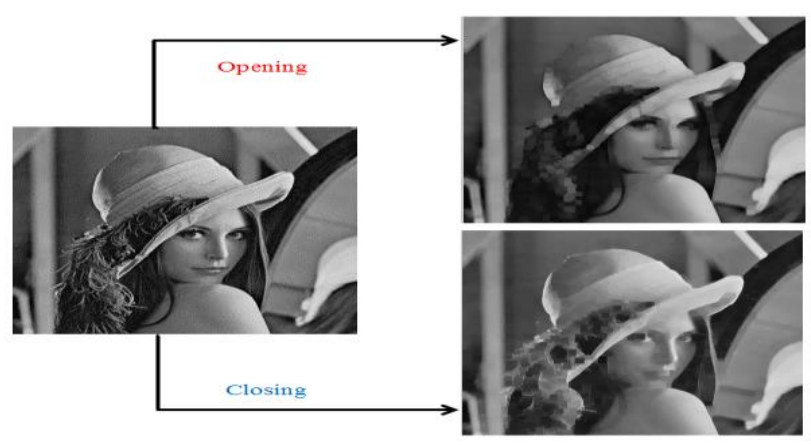

Figure 1. The difference between the opening and

\section{Grayscaling (RGB Conversion)}

In this process, the image of the resizing result is further processed by converting the image into a grayscale image (grayscale). Because the image resizing results is an image with RGB color model. This color model is too complex because it uses three color layers, namely Red, Green, and Blue.

\section{Dilation}

This dilation uses a disk, line, and rectangle-shape of strel. Because these shapes are common strel use in detection purpose. In addition, disk strel is the most common form used in morphological processes. The resulting effect is evenly distributed in all directions, so it will make it easier to do the next process. 


\section{Opening}

Furthermore, the image of dilation result is processed by using opening operation. Removal of the treated parts by opening operation horizontally and vertically to obtain an easier image to be processed at the verification stage.

\section{Performance evaluation}

We applied the ratio of edge pixels to the image size to assess the proposed method. The formula for the ratio calculation was expressed as follows:

nnz (Y)/prod (size (X)

where $\mathrm{Y}$ is the detection edge rate of bw (black-white) image, $\mathrm{X}$ is the detection edge rate from the original image. The ratio of edge pixels to image size measures the relative number between pixels of edges and the total image size. A greater ratio means that the proposed edge detector identified more edge pixels.

\section{EXPERIMENT AND RESULTS}

First, the results of each stage we group by the method of edge detection, that is with canny and with sobel. After these two operations are performed, we then note the results of the ratio between the number of edges and the number of initial image pixels before being given a canny or a sobel operation. Results are presented in Table $1 \& 2$, where the original image is shown in Fig. 2.

For first image (coin) dilation operation can increase the ratio either with strel (structure element) in the form of disk, line, or rectangular. Then in the second picture, the operation of the dilation also increases the ratio value. However, for opening operation is not better because it detects fewer edges. The same thing in the third image (original pattern cube) either by dilation or opening method, but the increase is not significant. For the fourth and fifth objects, from four experiments for the sobel method only succeeded in an increase of the dilation operation by using line strel.

TABLE 1. The ratio of edge pixels to image size using Canny

\begin{tabular}{lllllll}
\hline Image & edge & \multicolumn{2}{l}{ Dilation } & \multirow{2}{*}{ opening } \\
\cline { 4 - 6 } & method, value & disk & line & rec & \\
\hline coin & Canny, & 0.0094 & 0.0094 & 0.0102 & $\mathbf{0 . 0 0 9 9}$ & 0.0093 \\
\hline matches & Canny, & 0.0376 & 0.0442 & $\mathbf{0 . 0 4 5 0}$ & 0.0439 & 0.0238 \\
\hline original & Canny, & 0.0059 & 0.0061 & 0.0060 & $\mathbf{0 . 0 0 6 8}$ & 0.0061 \\
\hline kos & Canny, & 0.0111 & 0.0093 & $\mathbf{0 . 0 1 1 2}$ & 0.0094 & 0.0094 \\
\hline lefe & Canny, & $\mathbf{0 . 0 1 9 9}$ & 0.0096 & 0.0176 & 0.0169 & 0.0108 \\
\hline
\end{tabular}

TABLE 2. The ratio of edge pixels to image size using Sobel

\begin{tabular}{lllllll}
\hline Image & \multirow{2}{*}{$\begin{array}{l}\text { edge } \\
\text { method, value }\end{array}$} & \multicolumn{2}{l}{ Dilation } & \multicolumn{2}{l}{ opening } \\
\cline { 3 - 5 } & & disk & line & rec & \\
\hline coin & Sobel, & 0.0088 & 0.01 & $\mathbf{0 . 0 1 0 6}$ & 0.0102 & 0.0100 \\
\hline matches & Sobel, & 0.0369 & 0.0472 & 0.0450 & $\mathbf{0 . 0 4 8 2}$ & 0.0246 \\
\hline
\end{tabular}




\begin{tabular}{|c|c|c|c|c|c|}
\hline \multirow[t]{2}{*}{ Image } & \multirow{2}{*}{$\begin{array}{l}\text { edge } \\
\text { method, value }\end{array}$} & \multicolumn{3}{|c|}{ Dilation } & \multirow[t]{2}{*}{ opening } \\
\hline & & disk & line & rec & \\
\hline orginal & Sobel, 0.0061 & 0.0065 & 0.0063 & 0.0065 & 0.0065 \\
\hline kos & Sobel, 0.0112 & 0.0093 & 0.0115 & 0.0097 & 0.0097 \\
\hline lefe & Sobel, 0.0163 & 0.0106 & 0.0185 & 0.0166 & 0.0099 \\
\hline
\end{tabular}

From the experimental results it can be seen that the image containing the elements of the two-dimensional space building, tends to increasing result for every morphology like dilation and opening operation. While the image with the building element or 3-dimensional shape is less suitable because there is no increase in the results when morphological

operations (dilation, opening) operated. We also experimented with several images with combination of some varian strel. First for imagery like 'kos' (Fig.2 b) with some strel and radian positions sets as follows:

$$
\begin{aligned}
& \text { se_15= strel('line',5,270); } \\
& \text { se_16 = strel('line',6,300); } \\
& \text { se_14 = strel('line',6,120); } \\
& \text { se_13 = strel('line',10,120); } \\
& \text { se_12 = strel('line',5,120); } \\
& \text { se_1 = strel('line',5,0); }
\end{aligned}
$$

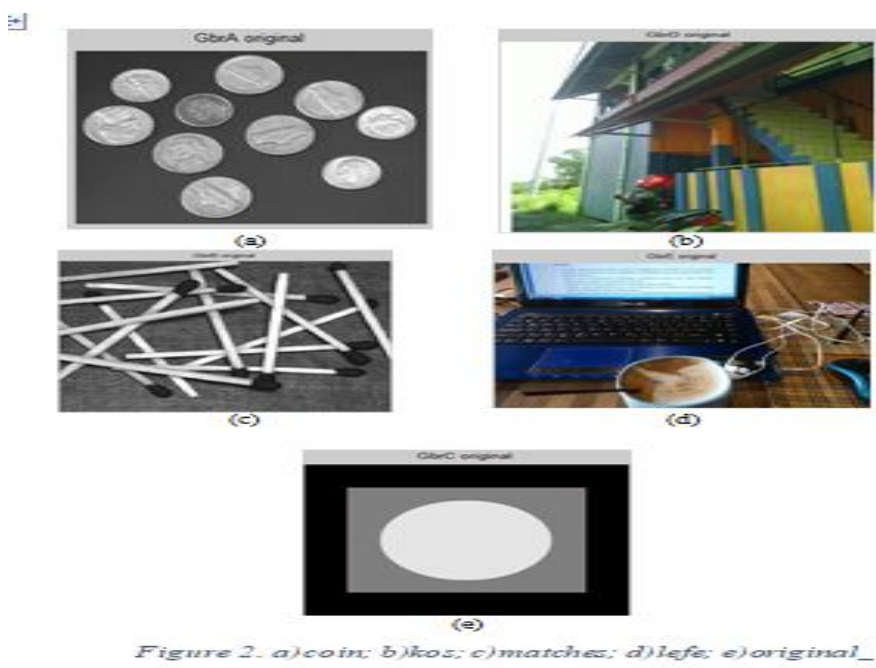

the results shown vary. The hypothesis obtained is the degree of strel (line strel) slope, not affect enough on the results. More important is dependent on the image and which image elements used as strel. Similarly, the change of some strel shape between disk, rectangle, line, octagon, and square was not quite different in generating value respectively. Visually, Fig. 3 shows the results of previous experiments details in Table 1. 


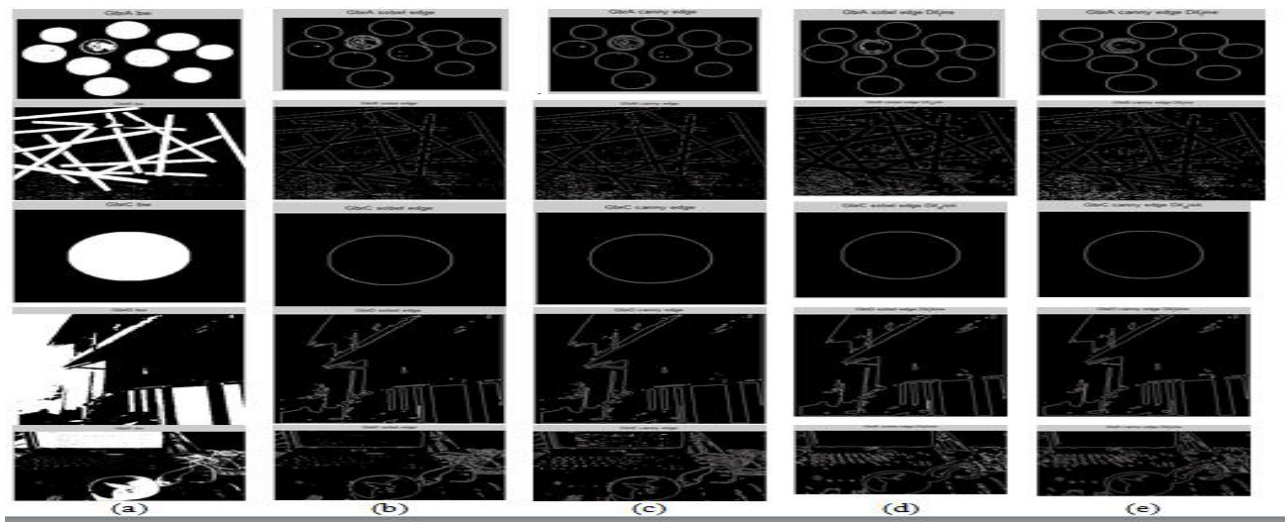

Figure 3. a)Black and white form b). Edge generated by sobel c)Edge generated by canny d)

Sobel after morphology operation e) canny after morphology operation

\section{ONCLUSION}

Dilation operation using strel line is more effective than other strel type. This is because the degree feature that provides many options depends on the image.

The morphological operation which is an old method can still be used with some method improvements eg with a combination of sobel or canny operations. From the experiments that have been done can be concluded that the morphological method is very useful to form a more easily recognizable image in proper to image enhancement process. Operation or technique on morphology such as Dilation, Opening, and Closing can be widely applied to the image and better on the grayscale image.

\section{References}

[1] Fahmi, "Perancangan Algoritma Pengolahan Citra Mata Iris Sebagai Bentuk Antara Sistem Biometrik," Dep. Tek. Elektro, Medan, 2007.

[2] P. Soille, Morphological Image Analysis: Principles and Applications. Springer-Verlag New York, Inc., 2003.

[3] S. Mohammad, A. Hasan, and K. Ko, "Depth edge detection by image-based smoothing and morphological operations," J. Comput. Des. Eng., vol. 3, no. 3, pp. 191-197, 2016.

[4] A. M. Raid, W. M. Khedr, M. A. El-Dosuky, and M. Aoud, "Image Restoration Based on Morphological Operations," Int. J. Comput. Sci. Eng. Inf. Technol., vol. 4, no. 3, pp. 9-21, 2014.

[5] Arini, F. Fahrianto, A. Agusta, and A. T. Muharam, "Pendeteksian Posisi Plat Nomor Mobil Menggunakan Metode Morfologi Dengan Dilasi, Filling Holes Dan Opening," J. Tek. Inform., vol. 8, no. 1, pp. 10-15, 2015.

[6] R. Supriyanti, A. Chrisanty, Y. Ramadhani, and W. Siswandari, "Computer Aided Diagnosis for Screening the Shape and Size of Leukocyte Cell Nucleus based on Morphological Image," Int. J. Electrical Comput. Eng., vol. 8, no. 1, pp. 150-158, 2018.

[7] M. Kowalczyk, P. Koza, P. Kupidura, and J. Marciniak, "Application of Mathematical Morphology Operations for Simplification and Improvement of Correlation of Images in Close-Range Photogrammetry," Int. Arch. Photogramm. Remote Sens. Spat. Inf. Sci., vol. 37, pp. 153-158, 2008.

[8] N. Trisnadik, A. Hidayatno, and R. Rizal, "Pendeteksian Posisi Plat Nomor Kendaraan Menggunakan Metode Morfologi Matematik," TRANSIENT, vol. 2, 2013.

[9] Masfran, Ananda, and E. Setyo, "Segmentasi Tepi Citra CT Scan Paru-paru 
Menggunakan Metode Chain Code dan Operasi Morfologi,” no. 1, pp. 6-11, 2014.

[10] S. Ashraf and A. Fariha, "An Efficient Method for Extracting Subtrees Against Forest Query," pp. 0-6, 2015. 